Ernst Wolff

Between Daily Routine and Violent Protest 

Ernst Wolff

\section{Between Daily Routine and Violent Protest}

Interpreting the Technicity of Action

\section{DE GRUYTER}




\section{KU LEUVEN}

The publication of both paper and OA versions of this book was made possible by Internal Funds from the KU Leuven.

ISBN 978-3-11-072497-4

e-ISBN (PDF) 978-3-11-072504-9

e-ISBN (EPUB) 978-3-11-072514-8

DOI https://doi.org/10.1515/9783110724974

\section{(cc) BY-NC-ND}

This work is licensed under the Creative Commons Attribution-NonCommercial-NoDerivatives 4.0 International License. For details go to http://creativecommons.org/licenses/by-nc-nd/4.0/.

Library of Congress Control Number: 2021905145

\section{Bibliographic information published by the Deutsche Nationalbibliothek}

The Deutsche Nationalbibliothek lists this publication in the Deutsche Nationalbibliografie; detailed bibliographic data are available on the Internet at http://dnb.dnb.de.

(C) 2021 Ernst Wolff, published by Walter de Gruyter GmbH, Berlin/Boston The book is published open access at www.degruyter.com.

Printing and binding: CPI books $\mathrm{GmbH}$, Leck

www.degruyter.com 